\title{
ERNESTO PATERNIANI (1928-2009): A life devoted to Genetics and Breeding
}

Paterniani was born in the city of São Paulo on February $17^{\text {th }}, 1928$, the son of Italian immigrants. Early in life, he and his family moved to Piracicaba. On arriving, his parents took over a grocery store. After going through primary, secondary and high school courses in public schools, in 1947 he entered the local Escola Superior de Agricultura "Luiz de Queiroz" (ESALQ) - of the University of São Paulo (USP), in order to study agronomy. Throughout his studies he was always interested in Genetics. He graduated in $2^{\text {nd }}$ place in 1950 .

In 1951, he received a grant from the Rockefeller Foundation, as part of special training for recently graduated agronomists in the Mexican Agricultural Program with Dr. E.J. Wellhausen. This was when he began his research on corn improvement.

In 1952, he was hired as assistant of the $19^{\text {th }}$ Chair in Cytology and General Genetics, which, in 1970, was transformed into the Department of Genetics of ESALQ/USP, where he stayed until retirement in 1983 as a Full Professor. He dedicated his entire life to the genetic improvement of corn.



E. Paterniani, April 2004 (Photographed by Paulo Soares).
In 1954, he submitted his doctor's thesis "Studies on Native Corn Races" under the advisory of Prof. Friedrich Gustav Brieger. He developed his post-doc studies (19571958) at the University of Nebraska with Prof. John H. Lonquist, and at Iowa State University with Prof. G.F. Sprague. His professor thesis "Interracial Crosses of Corn" was submitted in 1962 at ESALQ. He became full professor in 1975.

After retiring in 1983, Prof. Paterniani continued working as a consultant and assistant until his death.

He was outstanding as a teacher of Genetics and Plant Breeding in undergraduate and graduate courses, where he was respected and admired by all his students, having to his merit facility in communication, excellent didactics and a deep scientific knowledge of Genetics and Breeding. He stimulated his students to discuss controversial subjects in the classroom, these debates often extending beyond the specified time. Paterniani took an active part in seminars of the Department of Genetics, in constant debate with other professors, mainly with Prof. Marcílio Dias, when polemic aspects of Genetics and Breeding came under discussion. This exchange of opinions awakened the students' interest, inciting their active participation in lectures and seminars. His participation in Congresses and Symposia was also outstanding, and even in other scientific areas, he always took active part with questions, animating the procedures in a positive manner.

He orientated 33 students in science-initiation, 30 master dissertations and 13 doctors' theses in Genetics and Breeding graduate courses at ESALQ.

The main characteristic of his teaching and research activities was always to be working constantly and persistently with corn (from 1952 to 2009). It was through this persistence and by always seeking to perfect his techniques through innovation that, doubtlessly, he managed to contribute in divulging the name of the Department of Genetics, ESALQ as a center of reference in Breeding, both in Brazil and abroad.

In his breeding activities, Paterniani did not produce hybrids of inbred lines. His sphere of action was concentrated on recurrent selection, aimed at increasing the frequency of favorable alleles in open pollinated or panmictic populations. In this way he produced improved varieties as well as superior intervarietal hybrids. Later on, this material served as source for inbred lines, used in programs of private seed companies.

In the early years in Brazil the improvement of corn was not an easy task. Genetic material from abroad was not adapted to local conditions. Furthermore, native types con- 
sisted of plants with an outdated and inadequate architecture. Because of this and in order to start a long-term program, Paterniani began by forming a germoplasm bank from local material and entries introduced from other regions, mainly from Mexico. His preoccupation in promoting the introgression of genes from other regions became evident in his thesis for Full-Professorship, entitled "Interracial Crosses of Corn" (1962). It was through introgression and further selection that he obtained the Piramex variety, a denomination which reflects the mixture of local and Mexican germplasm. Later he obtained another more improved variety called Centralmex, with a wider capacity of adaptation, to the point that initially used in the southeastern and central-western regions, it later spread to northeastern Brazil, where it remained for several years.

The genetical and experimental designs used by Paterniani had an important peculiarity, in that they permitted estimating quantitative genetic parameters resulting from additive gene effects. Thus, and as an additional outcome of his research, many articles on Quantitative Genetics with useful information for selection programs were published containing estimates of these parameters.

For a long time, the impact of corn breeding efforts at the farmer's level was under debate. Detailed research, undertaken to measure genetic advances attained throughout decades, showed that selection had generated an increase in grain production of at least 2 percent yearly. This well reflected the return of all the efforts made by improvement, with Paterniani as its main mentor and stimulator. These $2 \%$ accumulated over several years have resulted in a considerable amount of grain in the country.

It is interesting to recall that in 1962 he was hired for part-time work in the Department of Biology of the then Faculty of Philosophy, Sciences and Humanities in Rio Claro. He considered this as a challenge, as there he would be required to teach Evolution. Later, he commented on this period in Rio Claro as having been both worthwhile and gratifying. It was probably due to this novel activity that, in the same year and in Piracicaba, he did research on the development of reproductive isolation by means of selection. He wished to check Dobzhansky's conjecture that such isolation could arise within a population and in a sympatric manner. He started with two populations where the flowering period coincided perfectly, and by using two marker loci whose genes manifested the xenia effect in grain texture and color. For each generation he always eliminated those grains arising from interpopulation crossing, maintaining only those from intrapopulation fertilization. By repeating this selective process and after five generations, he managed to raise two new populations practically isolated in reproductive terms. It is important to note that the markers used exerted no action on the reproductive system. After publication in 1969 , this article became obligatory reading in international courses on evolution. The possibility of the occurrence of reproductive isolation through a sympatric process had been proven, as defended by Dobzhansky. The curious side of the fact, always commented on by $\mathrm{Pa}-$ terniani, is that he became more known internationally through this article than by so many others that he published on corn breeding.

On recalling the life and work of Paterniani, it is necessary to point out his various professional activities, as well as the prizes and distinctions he received in acknowledgement of his work.

He was the head of the Department of Genetics at ESALQ (1974 to 1983), Coordinator of the Graduate Program on "Genetics and Plant Breeding" at ESALQ (1974 to 1982), President of the Graduate Commission at ESALQ (1978-1979), President of the Lectureship and Research Commission at ESALQ (1977-1978), President of the Commission on Academic Activities at ESALQ (19811983) .

Outside ESALQ, Prof. Paterniani worked as advisor to CNPq, EMBRAPA, FAPESP, FINEP, the Polar Foundation (Venezuela) and FAO (Italy). He was also active together with researchers from the Agricultural Institute of Campinas, EMBRAPA and seed companies. Nowadays, ex-pupils of Prof. Paterniani occupy outstanding positions in seed enterprises, especially in those working on genetic improvement.

He was also outstandingly active at CTNBio in Brasília, especially in the area of transgenics.

He was editor of the journal Maydica (Italy), senior editor of Genetics and Molecular Biology of the Brazilian Society of Genetics (SBG) and chief editor of the journal of the Brazilian Association of Corn and Sorghum Improvement. He was also president of SBG (1972-1974).

During his life he received the following prizes and distinctions:

- 1950 - Prize Navarro de Andrade; $1^{\text {st }}$ place for the work "Obtainment of Eucalyptus Seedlings", when graduating at ESALQ.

- 1950 - Prize Epitácio Pessoa; $2^{\text {nd }}$ place on graduating from ESALQ.

- 1971 - Conferee Professor in Agronomical Sciences of CNPq.

- 1975 - Founder-Member of the Academy of Sciences of the State of São Paulo.

- 1978 - Prize from the "Fundazione Tito V. Zapparoli", Italy, for the paper " Reciprocal recurrent selection based on half-sib progenies and prolific corn plants (Zea mays L.)".

- 1983 - Silver Jubilee Medal of CNPq.

- 1983 - Member of the Brazilian Academy of Sciences, Biological Sciences Section.

- 1988 - Prize Almirante Álvaro Alberto of $\mathrm{CNPq} / \mathrm{MCT}$.

- 1992 - Prize Frederico de Menezes Veiga, of EMBRAPA. 
- 1995 - Member of the Academy of Sciences of the Third World.

- 1995 - Knight of the National Order of Scientific Merit of the Presidency of the Republic.

- 2000 - Grand-Cross of the National Order of Scientific Merit of the Presidency of the Republic.

- 2005 - The Bunge Foundation Prize, 2005, in the area of Agrobusiness, category Life and Work.

- 2009 - Prize Conrado Wessel, granted to personalities in socially recognized entities in the Sciences.
Prof. Ernesto Paterniani was married to Mrs Yanned Paulina Stipp Paterniani, leaving children and grandchildren. He died in Piracicaba on June 18 ${ }^{\text {th }}, 2009$.

Roland Vencovsky Gerhard Bandel

Departamento de Genética, Escola Superior de Agricultura "Luiz de Queiroz", Universidade de São Paulo, Piracicaba, SP, Brazil 